\title{
Evidence for the Relevance of Secondary Stress in German: Prosodic Restrictions in Verbal Prefixation with ver-
}

\begin{abstract}
This contribution deals with secondary stress in Modern Standard German (MSG) and its relevance in affixation using the verbal prefix ver-. While the pattern ver+stressed syllable or ver+schwa is allowed, ver+unstressed syllable is avoided in contemporary German (see also Kaltenbacher 1999). Diachronical data reveals that in earlier stages this prosodic restriction was not as strong as in MSG. The consistency with which verbs with the pattern ver+unstressed syllable are discarded in MSG (confirmed by look-ups in corpora and dictionaries) is a strong argument for the hypothesis that the relinquishment is due to a form of blocking related to the stress properties of the direct base: The affix ver- needs a direct base with some initial prominence, that is with primary or secondary stress. The only (apparent) exception to this stress condition is a base containing a schwa syllable which seems to be "invisible" for the stress-seeking prefix. Verbal derivation with the prefix ver- demonstrates that the stress properties of the base have to be taken into account also with regard to secondary stress. The data provided in this paper can count as further evidence for the existence and relevance of secondary stress in Modern Standard German and its interaction with morphology.
\end{abstract}

\section{Keywords}

secondary stress, German, verbal derivation, stress-sensitivity 


\section{Introduction}

In Modern Standard German (MSG), verbal derivation with the prefix vershows the following patterns:

(1) Verbal derivation with ver-:
a. ver+primary stress:
spíelen
verspielen
ver+secondary stress:
'to play'
'to gamble away'
tèlefonieren
vertèlefonieren
'to phone'
'to make the wrong phone call'
b. ver+schwa
G[ə]wált
verg[ə]wáltigen
'violence'
'to violate'
c. ver+unstressed syllable:
kopieren
'to copy'
*verkopieren

As the table shows, derivation with ver- to a base with initial unstressed syllable is avoided in contemporary German (1c.), cf. also Kaltenbacher (1999). ${ }^{1}$ Diachronical data reveals that in earlier stages this prosodic restriction was not as strong as it is in contemporary German. In the digital version of the DWb (Deutsches Wörterbuch), started in 1838 by Jacob and Wilhelm Grimm and containing the whole German word "treasure" with reference sources since the $16^{\text {th }}$ century, 37 examples can be found in which ver- is attached to a base starting with an unstressed syllable (see also Henzen 1956):

(2) Outdated verbs prefixed with ver- (bases are still in use in MSG)
a. ver-maskíeren
(base: maskíeren 'to mask')
b. ver-ballásten
(base: Ballást 'ballast')

Of the 37 entries with pattern 1c. listed in the DWb, 34 are no longer present in MSG. This is documented by dictionary look-ups (Duden 2005; Krech et al. 2009; Mater 2006) and by searching the corpora of the DWDS (Digitales Wörterbuch der deutschen Sprache). In MSG only the two antiquated verbs verlustieren 'to amuse oneself' and verschimpfieren 'to denigrate' seem to be marginally present. They are listed in the above-mentioned dictionaries (signaled however as "antiquated") and are detected in the DWDS core corpus: 3 hits for verschimpfier ${ }^{*}$ in the core corpus (1990-1999) and 14 hits for verlustier ${ }^{\star}{ }^{2}$ Further, the verb verpers'önlichen is found in the DWDS core corpus (1990-99,

\footnotetext{
${ }^{1}$ See also Ito and Mester (2009) who claim that in MSG a foot has to be built at the left edge of a prosodic word (PARSE-INTO-FOOT) allowing the attachment of an unstressable prefix (containing a schwa syllable, like e.g. the prefix g[ə]-) only to main stress.

${ }^{2}$ The DWDS core corpus is a reference corpus for $20^{\text {th }}$ century German language and contains approximately 100 million running words, balanced chronologically and by text genre in approximately 80,000 documents, https://www.dwds.de/r? corpus=kern [28.12.2018].
} 
6 hits). The Frequency Dictionary German $(2011)^{3}$ does not enlist any of the above-mentioned words among the 10.000 most frequently occurring word forms in the German language. However, verlustieren and verlustiert are found among the 1.000.000 most frequently occurring word forms, but in the very low frequency classes 19 and 20 respectively, while verschimpfieren ist not enlisted at all. Ito and Mester (2009) mention verstudieren, but the verb is no longer listed in current dictionaries, nor is it found in the DWDS core corpus or in the Frequency Dictionary German, while it is present in the historical sources of the DWDS (3 hits, from 1605, 1729, 1887). Searching on Google a reviewer found verkopieren which, however, is not present in any of the above-mentioned corpora. Both word forms, verkopieren and verstudieren, are not enlisted in the Frequency Dictionary German. To sum up, only verlustieren seems to be marginally present in MSG.

The consistency with which the verbs with pattern 1c. are discarded in MSG is a strong argument for the hypothesis that their relinquishment is due to a form of blocking related to the stress properties of the direct base given that also no new verbs with this pattern enter the lexicon. This is not the case for derivations with the other patterns, including derivations to bases with secondary stress, see e.g. vertèlefonieren 'to make the wrong phone call', veràbsolutíeren 'to make sth (into) an absolute', verbàrrikadieren 'to barricade', verkomplizieren 'to complicate' and others), which are not present in the DWb.

In the following sections, the obsolescence of pattern 1c. in MSG will be interpreted as a form of "blocking" in connection with the stress properties of the direct base that needs some initial prominence (including secondary stress).

The paper is organized as follows: in section 2 I will briefly illustrate how phonologically conditioned gaps ("blocking") in derivational morphology are discussed in literature (cf. e.g. Shih 2017; Raffelsiefen 1996). Kager (2000), for example, uses "blocking" to analyse affixation in modern Dutch related to suffixes and interacting with primary stress. Subsequently, the analysis will be extended to prefixation and secondary stress in MSG. Section 3 will provide a short review of secondary stress in MSG, section 4 will outline the phonological properties of the prefix ver- and in section 5 an OT-analysis will be discussed. Eventually, conclusions will be drawn in section 6, highlighting that prefixation with ver- not only illustrates a form of stress-sensitivity related to prefixation, but it is also a pointer to the existence and relevance of secondary stress in MSG and its interaction with morphology.

${ }^{3}$ The Corpus is based on 3 different sources: newspaper texts (approx. 120 million sentences); randomly selected texts from the WWW (approx. 100 million sentences), the German edition of Wikipedia from the year 2009 (approx. 9 million sentences), cfr. Quasthoff et al. (2011). 


\section{Stress-sensitivity in affixation}

Following Kager (2000) stress-sensitivity of affixes comes in two ways: affixes can "actively" cause a certain prosodic pattern in the base (leading to a stress shift in the direct base) or "passively" block affixation, that is affixation cannot take place if certain prosodic conditions in the base are not met. An example for affix "activity" in Dutch is the adjectival suffix -ig which shifts the stress of a compound base from the first member to the second, that is to the syllable directly preceding it.

(3) Example for "active" affixes in complex words:

Nóod-lot 'fate' [nood-lót]-ig 'fatal'

bases: nóod 'distress'; lót 'fortune'; nóod-lot 'fate'

Stress shift is not possible with affixed bases: in (4), affixation with -ig cannot activate a stress shift to the adjacent syllable; suffixation with -ig is blocked:

(4) Example for "passive" affixes: suffixation with -ig is blocked:

[wáar-heid] 'truth' *[[waar-héid]-ig]

bases: wáar 'true'; wáar-heid 'truth'

Kager models the interaction between stress and stem-based affixation with the help of output-output faithfulness: stress shift is possible in (3) as it respects a constraint that requires the derived word (nood-lót-ig) to have a corresponding stress peak on some base (lót), although it is not present at the moment of derivation.

By contrast, the example in (4) shows a stress induced gap ("blocking"): the suffix -ig attaches only to bases with adjacent stress, but in (4) there is no corresponding stress peak on the suffix [-heid], even not at earlier stages of derivation; thus, suffixation with -ig is blocked.

I will adopt Kager's model applying it to verbal prefixation in German with ver-. With the help of the constraint system proposed in Kager (2000) it is possible to explain why certain verbs prefixed with ver- are disappearing in Modern Standard German (MSG). The relinquishment of these prefixed verbs is a form of "blocking": verbal derivation with ver- needs a base with primary or secondary stress at the left edge.

\section{Secondary stress in Modern Standard German}

Phonetic transcriptions of prosodic patterns in longer German words mostly disregard secondary stresses presumably due to the difficulty to capture their phonetic properties (Kleber and Klipphahn 2006). This acoustic non-detectability has led some researchers to question even its existence - compare e.g. 
Moulton (1962), regarding loan words with more than three syllables, such as immatrikulieren 'matriculate' or Wiese (2000: 275) who excludes secondary stress in post tonic positions within words. ${ }^{4}$ Among pronunciation dictionaries only the Deutsches Aussprachewörterbuch (Krech et al. 2009) signals secondary stress in the case of non-native words with at least 4 syllables preceding main stress on the first syllable (5a) - with the exception of prefixed words $($ see $5 b)$
(5)
a. Fàl.si.fi.ka.tión 'falsification'
[f,alzifikatsio:n]
b. ver-bàr.ri.ka.díe.ren
'to barricade' ver-àb.so.lu.tíe.ren
'to make sth (into) an absolute'

Nonetheless, secondary stress is part of the knowledge of speakers (Alber 1997, 1998). In emphatic speech, secondary stress can be upgraded to primary stress (Krech et al. 2009; Berg 2008) which shows that it must have the potential to stress.

ERP-studies provide also convincing evidence for secondary stress. In stress-evaluation experiments (see Dohmas et al. 2008), participants were confronted with correctly and incorrectly stressed trisyllabic words containing a. only one foot and stress on the penultimate - e.g. bi(kini) 'bikini'- and b. trisyllabic words with two feet and primary stress on the ultimate - e.g. (vita) (min) 'vitamin'. Results show that incorrectly stressed words lead to enhanced late positivity effects if metrical structure is altered (in the case of an incorrectly stressed form like ${ }^{\star}($ biki)ni). By contrast, with regard to trisyllabic, bipodal words in which only first and secondary stresses are switched - e.g. ${ }^{*}(v i t a)$ (min) - late positivity effects are less strong; cf. Domahs et al. (2008). The difference in acceptability can be explained if we assume two metrical feet in the latter case: shifting main stress to a syllable which is however the head of a foot (with secondary stress) is better than shifting main stress to an unfooted syllable without stress. See also Knaus et al. (2011) for further evidence.

Phonological studies concerned with the placement of secondary stress in German assume that secondary stress starts at the left edge of the prosodic word building a trochaic, binary foot. For this reason, it is also called initial secondary stress (ISS), cf. Kristoffersen (2007: 163). Two stressless syllables preceding main stress are not allowed $\left({ }^{*} \sigma \sigma^{\prime} \underline{\sigma}\right)$. This prosodic restriction is supported by the structure of the lexicon: in German, there are no unprefixed words with two or more syllables preceding main stress starting with a schwa-syllable (compare e.g. ${ }^{\star} B[ə] . n e . f i z$ 'benefit', ${ }^{*} g[ə]$ neralisíeren 'to generalize' (Becker 1998: 109). If it is assumed that the initial position is predestined

\footnotetext{
${ }^{4}$ Cf. also Jessen (1999: 518): "Empirical information on the existence and patterning of secondary stress in the underived words of German is insufficient so far."
} 
for stress, clearly schwa syllables cannot occur in these contexts since they cannot receive stress.

The imperative to assign ISS at the left edge of unprefixed words with two or more syllables preceding main stress is not overridden by stress preservation or quantity sensitivity. These phenomena are observed in longer, non-native words, but only word medially (Alber 1997, 1998). On the contrary, primary stress on the second syllable in a word is completely removed in a derivation with a stressshifting suffix in order to establish a binary foot with secondary stress at the left edge, cf. e.g. Rivále 'rival' > Rivalität 'rivalry' and not *Rivàlität or Objékt 'object' $>$ óbjektivieren 'objectify' and not *objèktivieren which is a strong argument for initial secondary stress. (For details regarding stress preservation and quantity sensitivity see Alber 1997, 1998; Vogt 2015; an overview of arguments on initial secondary stress in MSG is given in Alber, in press).

The preceding description of ISS is related to unprefixed bases. The following section is dedicated to the stress properties of verbs derived with the verbal prefix ver-.

\section{Phonological properties of ver- in Modern Standard German (MSG)}

The "inseparable", bound ${ }^{5}$ prefix ver- which results etymologically from a combination of three prepositions - gothic faúr (vor[bei] 'past'), fra (weg von 'away from') and fair (hindurch 'through') -, has a strong tendency to combine with non-native bases (Fleischer and Barz 2012: 115) making it particularly suitable for investigation of interactions with secondary stress given that normally only non-native bases are long enough to show this second level of stress. ${ }^{6}$

The resulting prosodic patterns in verbal derivation with ver-, exemplified in the table in (1), are repeated here:

(1) Verbal derivation with ver-:

\begin{tabular}{|c|c|c|}
\hline$r+$ primary stress: & spielen & ver-spíelen \\
\hline & 'to play' & 'to gamble away' \\
\hline er+secondary stress: & tèlefonieren & ver-tèlefonieren \\
\hline & 'to phone' & 'to make the wrong phone call' \\
\hline $\begin{array}{l}\text { jer+schwa } \\
\text { er+unstressed syllable: }\end{array}$ & $\begin{array}{l}G[a] \text { walt } \\
\text { kopieren }\end{array}$ & $\begin{array}{l}\text { ver-g[ə]wáltigen } \\
{ }^{*} \text { ver-kopieren }\end{array}$ \\
\hline
\end{tabular}

${ }^{5}$ German derived verbs are divided into "separable" particle verbs with initial stress like áufmachen 'to open' and prefix verbs in which main prominence is on the verb, such as ver-tíefen 'to deepen. "Separable" means that in V2 contexts and in the imperative the separable prefix is realized postverbal, that is, in the second part of the "sentence bracket".

${ }^{6}$ See also Vogt 2015: Prefixation with the prefix ver- and its interaction with initial secondary stress are discussed, but not in detail. 
In la no secondary stress is assigned to ver-; in the derivation with a verbal base containing two or more syllables preceding primary stress, initial secondary stress is preserved on the base. ${ }^{7}$ In the pronunciation dictionary of Krech et al. (2009) - the only pronunciation dictionary that assigns secondary stresses (see section 3) - no verb prefixed with ver- is found with secondary stress on ver-. However, there are two entries in which secondary stress is signaled on the first syllable of the base: veräbsolutíeren 'to make sth (into) an absolute', verbàrrikadieren 'to barricade.'

The possibility of ver- being stressed or not is also related to the phonological status of the vowel in ver-. Following Wiese $(2000: 94,295)$ ver- is realized "at least underlyingly" with a full vowel; in a word such as $[(\mathrm{v}[\varepsilon] \mathrm{r})$.(ságt)] 'failed' the prefix is parsed into a foot, but not into a prosodic word, and it is - according to Wiese - always stressless as the other "true" prefixes, for instance er-and $z e r-$. Furthermore, in pronunciation dictionaries it is transcribed with a full vowel, compare e.g. [fere]'tiefen <vertiefen>, 'to deepen' (Duden 2005). Sometimes, vowel and postvocalic $/ \mathrm{r} /$ are transcribed with a so-called vocalized $/ \mathrm{r} /$ or low schwa (Duden 2006: 699), Krech et al. (2009): v[e] ságen <versagen>, 'to fail. This sound occurs only in unstressed syllables (Wiese 2000: 17).

In a nutshell, taking the different findings (assessments in literature, phonological status of the vowel) it could be shown that in type 1a. derivations the prefix is unstressed, while stress (primary or secondary stress) is preserved on the first syllable of the base. However, the prefix underlyingly contains a full vowel and is able to bear stress if attached to a base starting with a schwa syllable, see type $1 b$. verbal derivations: vèr-g[ə] wáltigen 'to rape', vèr-.b[ə]ámten 'to give so. the status of a civil servant'. If we take the 1a. derivations as evidence for ver-being attached only to syllables with some prominence at the left word edge of the base, in $1 \mathrm{~b}$. we have to assume that the syllable with schwa is somehow "invisible" to ver-. The stress-seeking prefix ver- skips the schwa syllable and attaches to the next syllable with some prominence. By skipping the initial schwa syllable, the stress-sensitivity of the prefix is respected. Secondary stress is assigned post-lexically to ver-for rhythmical reasons. In the following section analysis is outlined in the framework of the Optimality Theory (Prince and Smolensky 2004 [1993]).

\section{Analysis}

Kager (2000) explains the non-occurrence of certain affixes after complex words containing a stress-neutral suffix as blocking, due to constraints that require on the one hand adjacency of base and affix, and on the other

${ }^{7}$ See however Löhken (1997: 132) who assigns secondary stress on vèr- for theoretical reasons: vèr+éinigen. 
preservation of stress. The relevant examples with the Dutch suffix -ig in (3) and (4) are here repeated:

(6) "Active" affixes: stress is shifted from the first member of the compound to the second, preceding the suffix -ig:

Nóod-lot ,fate' -> [nood-lót]-ig (bases: lót, nóod, nóod-lot)

(7) "Blocking": suffixation with -ig cannot take place:

[wáar-heid] ,truth' -> *[[waar-héid]-ig], *[[wáar-heid $]-i g]$

(bases: wáar ,true’, wáar-heid ,truth')

Kager captures blocking with the help of the following constraints. Adjacency of the suffix with the base is captured by an alignment constraint: ${ }^{8}$

(8) ALIGN ( $\{-i g\}, \mathrm{L}$, stress peak, R):

"The left edge of the affix $\{-$ ig $\}$ coincides with the right edge of the syllable containing the stress peak of the word."

Preservation of stress in the derivation is expressed in Kager with the following DEP-constraint:

(9) PK-DEP (O/B): Let $\alpha$ be a segment in $\mathrm{O}$ and $\beta$ be its correspondent in $\mathrm{B}$.

If $\alpha$ is in the stress peak of $O$ then $\beta$ is in the stress peak of $B$.

"The stress peak in the derived word must match some stress peak in the base."

In a form like *[[wáar-heid] $-i g]$ stress is not adjacent to the affix, while a form like $*[[$ waar-héid $]-i g]$ would violate stress preservation since in both base forms, direct and indirect, stress is on [wáar] (direct base: [wáarheid]; indirect base: [wáar]). In this case a null parse $(\varnothing)$ is preferred. The null parse is expressed by the constraint M-MAX (I/O), (cf. Kager 2000):

(10) M-MAX (I/O): Every morpheme in the input has a correspondent in the output.

Both constraints, PK-DEP and ALIGN-TO-PEAK dominate M-MAX:

(11) $\emptyset>*[[$ waar-héid]-ig] PK-DEP » M-MAX

(12) $\emptyset>*[[$ wáar-heid]-ig] ALIGN-TO-PK » M-MAX

The null parse $(\varnothing)$ is preferred over violating stress preservation (11) and over violating adjacency (12). The result is "blocking".

Kager's approach is hereafter applied to ver- to explain "blocking" in the case of bases without some initial prominence (primary or secondary stress). The alignment constraint is accommodated to the prefix ver-as follows:

(13) ALIGN-TO-PK: ALIGN \{ver-\}, R, stress peak, L

"The right edge of the affix \{ver-\} coincides with the left edge of a syllable containing a stress peak in the direct base."

${ }^{8}$ The constraint and its denomination are slightly changed. 
The PK-DEP (O/B) constraint in (9) contains the specification that the stress peak in the derived form (output) must match some stress peak in the base. Vice versa, the location of stress peaks of the base must be preserved in the derived word (output), due to PK-MAX (B/O).

(14) PK-MAX (B/O): Let $\alpha$ be a segment in $B$ and $\beta$ be its correspondent in $O$. If $\alpha$ is in the stress peak of $B$ then $\beta$ is in the stress peak of $O$.

The last constraint which will be used in the following tableaux is the constraint that requires the realization of morphemes, here repeated:

(15) M-MAX (I/O): Every morpheme in the input has a correspondent in the output.

The following tableaux (16) and (17) illustrate pattern 1a. exemplified in section 1: affixation of ver- to a base with secondary stress; in (16) ISS is realized in the direct base on the second syllable preceding primary stress (ver-kòn.su.mieren); in (17) ISS is assigned in the direct base on the third syllable preceding primary stress (ver-àb.so.lu.tíeren). In the following tableaux the suffix -ieren is lexically specified as stressed. For suffixes of this type Kager assumes "brute-force" accentuation, presumably by input specification as well as top ranking peak faithfulness (Kager 2000: 7). ${ }^{9}$ This means that I do not contemplate output-candidates that do not respect this stressrequirement.

(16) ver-attached to a base with ISS

\begin{tabular}{|c|c|c|c|c|}
\hline $\begin{array}{l}\text { I: }\{\text { ver-, konsum-, -íeren\} } \\
\text { B: [kònsumíeren] }\end{array}$ & $\begin{array}{l}\text { ALIGN-TO- } \\
\text { PK }\end{array}$ & $\begin{array}{c}\text { PK-DEP } \\
(\mathrm{O} / \mathrm{B})\end{array}$ & M-MAX & $\begin{array}{l}\text { PK-MAX } \\
(\mathrm{B} / \mathrm{O})\end{array}$ \\
\hline \multicolumn{5}{|l|}{ a. [ver.kòn.su.míe.ren] } \\
\hline b. [vèr.kon.su.míe.ren] & *! & * & & * \\
\hline c. [vèr.kon.sù.míe.ren] & $* !$ & ** & & * \\
\hline d. $\varnothing$ & & & *! & \\
\hline
\end{tabular}

Shifting ISS from the direct base to the prefix (see b. and c.) would violate both the alignment constraint (ALIGN-TO-PK) and the stress preservation constraint PK-DEP $(\mathrm{O} / \mathrm{B})$, while a. respects them. Thus, a. is preferred over the null parse. The same hierarchy yields the correct result with an adjectival base, prefix conversion and secondary stress on the third syllable preceding primary stress in the direct base.

\footnotetext{
${ }^{9}$ Also following Wiese (2000) the suffix -ieren always requires main stress by input specification as well as top ranking peak faithfulness.
} 
(17) ver-attached to a base with ISS

\begin{tabular}{|c|c|c|c|c|}
\hline $\begin{array}{l}\text { I: }\{\text { ver-, absolut-, -íeren }\} \\
\text { B: [àbsolút] }\end{array}$ & $\begin{array}{l}\text { ALIGN- } \\
\text { TO-PK }\end{array}$ & $\begin{array}{l}\text { PK-DEP } \\
(\mathrm{O} / \mathrm{B})\end{array}$ & M-MAX & $\begin{array}{l}\text { PK-MAX } \\
(\mathrm{B} / \mathrm{O})\end{array}$ \\
\hline a. [ver.àb.so.lu.tíe.ren] & & & & * \\
\hline b. [vèr.ab.so.lu.tíe.ren] & $* !$ & * & & ** \\
\hline c. [vèr.ab.sò.lu.tíe.ren] & $* !$ & $* *$ & & $* *$ \\
\hline d. [ver.ab.sò.lu.tíe.ren] & $\star !$ & * & & ** \\
\hline e. $\varnothing$ & & & $* !$ & \\
\hline
\end{tabular}

In tableau (17) the candidate in a. respects the stress preservation (PK-DEP) and adjacency (ALIGN-TO-PK) constraint, thus it is preferred over the null parse $(\varnothing)$.

By contrast, the following tableaux (18) and (19) exemplify "blocking" in the case of verbal derivation with ver- to direct bases without initial prominence (cf. pattern 1c. in section 1):

(18) "Blocking": no prefixation with ver-

\begin{tabular}{|c|c|c|c|c|}
\hline $\begin{array}{l}\text { I: }\{\text { ver-, kop-, -íeren }\} \\
\text { B: [kopíeren] }\end{array}$ & $\begin{array}{c}\text { ALIGN-TO- } \\
\text { PK }\end{array}$ & PK-DEP & M-MAX & PK-MAX \\
\hline a. $\infty$ & & & * & \\
\hline b. [ver.kó.pieren] & & *! & & * \\
\hline c. [ver.kò.píeren] & & $* !$ & & \\
\hline d. [vèr.ko.píe.ren] & *! & * & & \\
\hline e. [ver.ko.píeren] & $* !$ & & & \\
\hline
\end{tabular}

Tableau (18) shows that the null parse is preferred over violating stress preservation (PK-DEP) in b. and c. and over violating adjacency (ALIGN-TO-PK) in $\mathrm{d}$. and e.

The same hierarchy rules out cases of prefix conversion with bisyllabic bases and initial stressless, pretonic syllable (cf. tableau 19):

(19) "Blocking": no prefixation with ver-

\begin{tabular}{|l|c|c|c|c|}
\hline $\begin{array}{l}\text { I: }\{\text { ver-, ballast, }- \text { en }\} \\
\text { B: }[\text { Ballást] }\end{array}$ & $\begin{array}{c}\text { ALIGN- } \\
\text { TO-PK }\end{array}$ & PK-DEP & M-MAX & P-MAX \\
\hline b. $[$ ver.bál.las.ten] & & & $*$ & \\
\hline c. $[$ ver.bàl.lás.ten] & & ${ }^{*}$ ! & & $*$ \\
\hline d. $[$ vèr.bal.lás.ten] & & ${ }^{*}$ & & \\
\hline e. $[$ ver.bal.lás.ten] & $* !$ & $*$ & & \\
\hline
\end{tabular}


Attaching ver- to a base starting with a stressless syllable calls for the construction of a trochaic foot with the syllable ver- as head (see section 3). It is promising to link the phenomenon not only to secondary stress, but to foot structure, too, rephrasing the alignment constraint as follows: ${ }^{10}$

(20) ALIGN-TO-F: ALIGN \{ver-\}, R, foot, L

"The right edge of the foot containing the affix $\{$ ver- $\}$ coincides with the left edge of a foot in the direct base."

In the case of bases with initial prominence, PK-DEP protects the initial syllable of the base from being integrated into a bisyllabic foot with ver- (cf. $*[(v e r$. ab.)(sò.lu.)(tíe.ren)] 'to make sth (into) an absolute', see tableau 21). Both, the bisyllabic and the bimoraic foot at the left edge (candidates b. and c.) cannot win against candidate a. which preserves ISS in the base:

(21) Base with stressed initial syllable

\begin{tabular}{|l|c|c|c|c|}
\hline $\begin{array}{l}\text { I: }\{\text { ver-, absolut-, -íeren\} } \\
\text { B: }[\text { àbsolút] }\end{array}$ & $\begin{array}{c}\text { ALIGN- } \\
\text { TO-F }\end{array}$ & $\begin{array}{c}\text { PK-DEP } \\
\text { (O/B) }\end{array}$ & M-MAX & $\begin{array}{c}\text { PK-MAX } \\
\text { (B/O) }\end{array}$ \\
\hline a. $[($ ver.)(àb.so.)lu.(tíe.ren)] & & & & $*$ \\
\hline b. [(vèr.ab.)(sò.lu.)(tíe.ren)] & & $* !$ & & $* *$ \\
\hline c. [(vèr.)(àb.so.)lu.(tíe.ren)] & & $* !$ & & $*$ \\
\hline d. $\varnothing$ & & & $* !$ & \\
\hline
\end{tabular}

The realization of a bisyllabic foot with ver- $\left({ }^{*}[\right.$ (vèr.ab.)(sò.lu.)(tíe.ren) $\left.]\right)$ would also lead to a mismatch between morphological and prosodic structure which is avoided in MSG. Prefixes such as ver- are not integrated into the following prosodic word. This is demonstrated i.a. by the lack of resyllabification and the insertion of a glottal stop at the metrical and morphological boundary, cf. e. $g$. ver.-[?]ár.men 'to impoverish'.

In the case of unstressed and unfooted initial syllables in the direct base (see tableau 22), candidate b. (with perfectly alternating rhythm) and candidate c. are excluded by PK-DEP as well. In addition, in c. also the alignment constraint is violated. Furthermore, it is not possible to shift primary stress to the initial syllable of the base (candidate c.):

${ }^{10}$ I thank one of the reviewers for this suggestion. 
(22) Base with unstressed initial syllable

\begin{tabular}{|l|c|c|c|c|}
\hline $\begin{array}{l}\text { I: }\{\text { ver-, ballast, -en }\} \\
\text { B: }[\text { Ballást] }\end{array}$ & $\begin{array}{c}\text { ALIGN- } \\
\text { TO-F }\end{array}$ & PK-DEP & M-MAX & P-MAX \\
\hline a. $\varnothing$ & & & $\star$ & \\
\hline b. $[$ (vèr.bal.)(lás.ten)] & & $* !$ & & \\
\hline c. $[$ (vèr.)bal.(lás.ten)] & $\star !$ & $*$ & & \\
\hline d. $[$ (ver.)(bál.las.)ten)] & & $* !$ & & \\
\hline
\end{tabular}

The last pattern to be explained is pattern $1 \mathrm{~b}$. Verbal derivation with the prefix ver- is often observed with a base containing an initial schwa-syllable. If a word form like verg[ə]wáltigen is possible, also *verkopieren should be allowed - from the point of view of rhythm. In literature, the exceptionality of syllables containing schwa is often highlighted. Wiese (2000: 99), for instance, states that prosodic restrictions in the allomorphy of the suffixes -heit/-keit in MSG are "blind" to the presence or absence of schwa syllables. Kager and Zonneveld (1986), Kager (2000) recall that schwa in final syllables behaves "as if not there". Therefore, it could be argued that the stress-seeking prefix ver-is "blind" to the presence of a schwa syllable. With schwa being "invisible" for verthe stress condition that the prefix imposes on its direct base is respected: veris attached to a base with initial prominence.

However, hereafter the hypothesis that the two prefixes g[a]- and b[ə]- are syllabic appendices that cause a change in the prosodic structure is defended: the two prefixes with schwa are prosodically weak and are integrated into a preceding foot. This prosodic restructuring is observed also in the case of particle verbs with separable prefixes.

Prefixes with the schwa syllable join the separable prefix and form a bisyllabic foot dominated by the highest projection of the prosodic word:

(23) [[(áuf.g[ə])] [(hò.ben)]] (Löhken 1997: 134)

The same restructuring can be observed in prefixation with ver-: the prefix together with the schwa appendix forms a trochaic, bisyllabic foot, which is by contrast to (23) not dominated by a prosodic word (cf. Löhken 1997: 132):

(24) [(vèr.g[ə])[(wál.ti)gen]]

In tableau (25) the prosodically unstable syllable with schwa is adjoined to the preceding ver- with which it forms a bisyllabic foot with internal, rhythmic stress pattern (vèr.b[ə]-). Thus, candidate a. respects all constraints; the foot containing the prefix ver-is aligned to the left edge of a stress peak in the direct base and there is correspondence of peaks between the derived form and its base. 
(25) ver-attached to a base with initial schwa syllable

\begin{tabular}{|c|c|c|c|c|}
\hline $\begin{array}{l}\mathrm{I}:\{\text { ver-, beamter, -en }\} \\
\mathrm{B}:<\mathrm{b}[\partial]>[\text { ámter }]\end{array}$ & $\begin{array}{l}\text { ALIGN- } \\
\text { TO-F }\end{array}$ & PK-DEP & M-MAX & PK-MAX \\
\hline \multicolumn{5}{|c|}{$\infty$ a. [(vèr.b[ə]).[(ám.ten)]] } \\
\hline b. [ver.b[ə].(ám.ten)] & *! & & & * \\
\hline C. $\varnothing$ & & & *! & \\
\hline
\end{tabular}

By contrast, in (22) the initial unstressed syllable bal- is headed by the prosodic word of the stem: thus, it is not possible to integrate the initial unstressed syllable into a foot with ver- and create a distinct prosodic domain.

\section{Conclusions}

In this contribution the relinquishment of a group of verbs prefixed with veris explained by way of stress-sensitivity of the affix and stress preservation. Data from pronunciation dictionaries and corpora show the disappearance from contemporary lexicon of German verbs prefixed with ver-attached to bases starting with an unstressed syllable $\left({ }^{\star}\right.$ verkopieren, ${ }^{\star}$ verspazieren $)$.

The resulting patterns are explained with the help of the constraint system proposed in Kager (2000) based on correspondence and adjacency. Prefixation with ver-thus demonstrates that the stress properties of the base and its foot structure have to be taken into account. Data can count as further evidence for the existence and relevance of secondary stress in Modern Standard German and its interaction with morphology.

\section{References}

Alber Birgit (1997). Il sistema metrico dei prestiti del Tedesco. Aspetti e problemi della teoria prosodica. Padova: University of Padova. PhD dissertation.

Alber Birgit (1998). Stress preservation in German loan words. In Phonology and Morphology of the Germanic Languages, Wolfgang Kehrein and Richard Wiese (eds.), 113-114. Tübingen: Niemeyer. ROA\#314

Alber Birgit (in press). Word-stress in Germanic. In Cambridge Handbook of Germanic Linguistics, Michael T. Putnam and Richard Page (eds.). Cambridge: Cambridge University Press.

Berg Thomas (2008). Emphatic stress shift in German. Zeitschrift für Sprachwissenschaft 27(2), 165-187.

Becker Thomas (1998). Das Vokalsystem der deutschen Standardsprache. Frankfurt am Main: Lang. 
Domahs Ulrike, Wiese Richard, Bornkessel-Schlesewsky Ina, Schlesewsky Matthias (2008). The processing of German word stress: Evidence for the prosodic hierarchy. Phonology 25(1), 1-36.

Duden (2005). Aussprachewörterbuch, Vol. 6. Max Mangold and Dudenredaktion (eds.). Mannheim: Bibliographisches Institut.

Duden (2006). Die Grammatik, Vol. 4. Max Mangold and Dudenredaktion (eds.). Mannheim: Bibliographisches Institut.

Fleischer Wolfgang, Barz Ingeborg (2012). Wortbildung der deutschen Gegenwartssprache. 4. ed. Berlin, Boston: Walter de Gruyter.

Henzen Wolfgang (1956). Der heutige Bestand der Verben mit ,ver-': Vorstudie zu einer Erforschung der Wortschatzbewegungen. In Fragen und Forschungen im Bereich und Umkreis der germanischen Philologie, Elisabeth Karg-Gasterstädt and Johannes Erben (eds.), 173-189. Berlin: Akademieverlag.

Ito Junko, Mester Armin (2009). The extended prosodic word. In Phonological Domains: Universals and Derivations, Baris Kabak and Janet Grijzenhout (eds.), 135194. The Hague: Mouton de Gruyter.

Jessen Michael (1999). German. In Word Prosodic Systems in the Languages of Europe, Harry van der Hulst (ed.), 273-334. Berlin: de Gruyter.

Kager René (2000). Stem stress and peak correspondence in Dutch. In Optimality Theory: Phonology, Syntax, and Acquisition, Joost Dekkers, Frank van der Leeuw and Jeroen van de Weijer (eds.), 121-150. Oxford: Oxford University Press.

Kager René, Zonneveld Wim (1986). Schwa, syllables, and extrametricality in Dutch. The Linguistic Review 5(3), 197-221.

Kaltenbacher Erika (1999). Prosodische Aspekte der Verbpräfigierung. Linguistische Berichte 180, 447-466.

Kleber Felicitas, Klipphahn Nadine (2006). An acoustic investigation of secondary stress in German. Arbeitsberichte Institut für Phonetik Kiel 37, 1-18. [URL: http:// www.ipds.unikiel.de/pub_exx/aipuk/aipuk_37/37_1_KleberKlipphahn.pdf; accessed January 11, 2018]

Knaus Johannes, Wiese Richard, Domahs Ulrike (2011). Secondary stress is distributed rhythmically with words: An EEG study on German. In Proceedings of the $17^{\text {th }}$ International Conference of the Phonetic Sciences 2011, 1114-1117. Hong Kong.

Krech Eva-Maria, Stock Eberhard, Hirschfeld Ursula, Anders Lutz Christian (2009). Deutsches Aussprachewörterbuch. Berlin, New York: de Gruyter.

Kristoffersen Gjert (2007). The Phonology of Norwegian. Oxford: Clarendon Press.

Löhken Sylvia (1997). Deutsche Wortprosodie: Abschwächungs- und Tilgungsvorgänge. Tübingen: Stauffenberg.

Mater Erich (2006). Gesamtverzeichnis deutscher Verben der Gegenwartssprache. Frankfurt/Main: Peter Lang Verlag.

Moulton William G. (1962). The Sounds of English and German. Chicago: University of Chicago Press.

Prince Alan, Smolensky Paul (2004) [1993]. Optimality Theory: Constraint Interaction in Generative Grammar. Oxford: Blackwell.

Quasthoff Uwe, Fiedler Sabine, Hallsteinsdóttir Erla (eds.) (2011). Frequency Dictionary German. Häufigkeitswörterbuch Deutsch. Leipzig: Leipziger Universitätsverlag.

Raffelsiefen Renate (1996). Gaps in word formation. In Interfaces in Phonology, Ursula Kleinhenz (ed.), 194-209. Berlin: Akademie Verlag. 
Shih Stephanie (2017). Phonological influences in syntactic choice. In The Morphosyntax-Phonology Connection, Vera Gribanova and Stephanie Shih (eds.), 223-252. Oxford: Oxford University Press.

Vogt Barbara (2015). Initial secondary stress in German. In pS-prominenceS. Prominences in Linguistics. Proceedings of the International Conference, Viterbo 1214.12.2013, Amedeo De Dominicis (ed.), 114-134, Disucom Press: Viterbo.

Wiese Richard (2000). The Phonology of German. Oxford: Oxford University Press.

\section{Internet Resources}

[URL: http://dwb.uni-trier.de/de/; accessed January 11, 2019]

[URL: https://www.duden.de/; accessed January 11, 2019]

[URL: https://www.dwds.de/r?corpus=kern; accessed January 14, 2019]

Barbara Vogt

Dipartimento di Scienze umane

Università degli Studi dell'Aquila

Viale Nizza 14

67100 L'Aquila

barbaramaria.vogt(at)univaq.it 
